\title{
The Impact of International Trade on Economic Growth: A Case Study of Pakistan
}

\section{Suleman Ghaffar ${ }^{1}$ \\ Dumaira Munir ${ }^{2}$ \\ Shahbaz Nawaz ${ }^{3 \rtimes}$ \\ Anam Javaid ${ }^{4}$}

'M.Phil, Public Administration, Department of ISS BZU, Multan, Pakistan.

Email:sh.sulemanghaffar@hotmail.com

${ }^{2} M S$ Economics, UMT Lahore, Pakistan.

Email: maierana20@gmail.com

${ }^{3}$ PhD Scholar, School of Quantitative Sciences Universiti Utara Malaysia.

Email: shahbazgurmanis1@gmail.com

${ }^{4}$ PhD Scholar, School of Mathematical Sciences Universiti Sains Malaysia and Lecturer, Department of Statistics, The Women University, Multan, Pakistan.

Email: anamjavaido786@yahoo.com

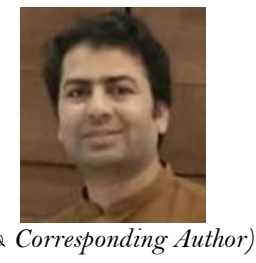

Abstract

International trade has its importance in economic growth of a country. Country that is good in international trade means that it is stable in its economic conditions. International trade also shows the relationship of a country with other countries. Pakistan also has relationship with other countries in terms of international trade throughout different years. Conducted study focus on international trade impact on economic growth in Pakistan. For this purpose, yearly data set is taken from period of 1972 to 2012. ARDL regression analysis is used to deal with see the long run and short run relationship among the effect of worldwide exchange on financial development of Pakistan. Descriptive statistics, KPSS unit root test and VIF are obtained for analysis purpose. Eview software is used to obtain results in analysis. The finding of this examination shows that outside direct speculation, genuine successful worldwide rate and urbanization have huge and negative effect on financial development. As worldwide exchange is arrangement instrument may have more impacts in future to the impact on exchange aggressiveness

Keywords: Impact, Trade, Economics, Pakistan, Growth, Trade balance, Exchange rate, Money supply.

Citation | Suleman Ghaffar; Humaira Munir; Shahbaz Nawaz; Anam Javaid (2019). The Impact of International Trade on Economic Growth: A Case Study of Pakistan. Asian Journal of Social Sciences and Management Studies, 6(2): 15-22.

\section{History:}

Received: 27 June 2019

Revised: 30 July 2019

Accepted: 2 September 2019

Published: 27 September 2019

Licensed: This work is licensed under a Creative Commons

Attribution 3.0 License (cc) $\mathbf{E}$ r

Publisher: Asian Online Journal Publishing Group
Acknowledgement: All authors contributed to the conception and design of the study.

Funding: This study received no specific financial support.

Competing Interests: The authors declare that they have no conflict of interests.

Transparency: The authors confirm that the manuscript is an honest, Transparency: The authors confirm that the manuscript is an honest,
accurate, and transparent account of the study was reported; that no vital accurate, and transparent account of the study was reported; that no vital
features of the study have been omitted; and that any discrepancies from the study as planned have been explained.

Ethical: This study follows all ethical practices during writing.

\section{Contents}

1. Introduction

2. Literature Review

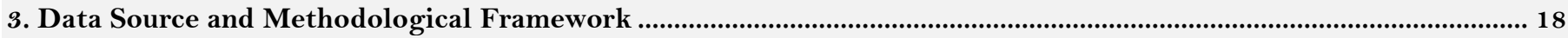

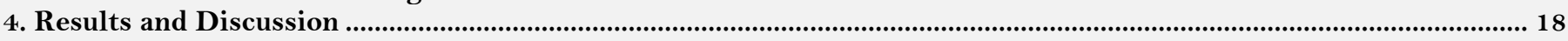

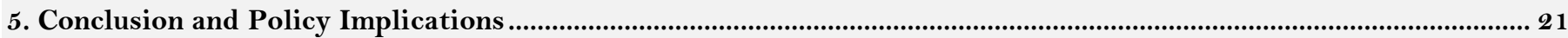

References 


\section{Contribution of this paper to the literature}

This study contributes to the existing literature by examining international trade impact on economic growth.

\section{Introduction}

Pakistan faces high boundaries to international trade over its eastern just as western and north-western fringes. Generally significant east-west trade courses associating India with focal Asia and China passed however Pakistan. Nonetheless, stressed relations with India, war and political precariousness in Afghanistan, absence of improvement of transportation foundation for land courses to China, and difficulty in inborn zones and Baluchistan have hindered Pakistan's trade towards east and west. Development of east-west trade displays an extraordinary open door for Pakistan to increment its economic growth (Nabi, 2013). There has been much enthusiasm for investigating the impact of trade progression with India. The ongoing China-Pakistan Economic Corridor (CPEC) venture has moreover animated enthusiasm for the potential for trade development with China.

Trade deficit is not generally a natural risky. It is persistence, size, and creation and causes of the deficit that determine if and to what extent the trade deficit should be a matter of concern. The exchange rate is an important policy variable that influences trade flows, capital flows, inflation, international reserves, and remittances. Many empirical results show how exchange rate changes affect the trade balance of developing countries. There is still the considerable disagreement that the effectiveness of currency deficit as a tool for increasing the international trade.

Along these lines, Pakistan is one of those nations who are going toward exchange lack from last different years. Pakistan was going toward exchange deficiency in budgetary year (FY) 1957-58. Outside exchange division was sensibly phenomenal amidst money related year 1953, 1954 and 1956. Its common tolls were 161 million US dollar more than its imports. In money related year 1956 - 57 and in budgetary year 2003-4 Pakistan has surplus change of exchange. This was the financial year in which Pakistan had a positive adjust of exchange. Regardless, these years Pakistan is confronting the issue of exchange and current record deficiency (Abbas, 2013). Later on a review on human development factors was made by Javaid et al. (2018) in Pakistan.

Moreover, Pakistan needs different financial arrangements to improve the adjust of exchange and increment the monetary action and development included like: levy structures, conversion scale, remote trade designation framework, import control and fare tax assessment. Pakistan should make and change their outside exchange strategies however nothing is done in this respects and the hole between exchange going extend step by step.

The critical success factors empirically examine the impact of exchange rate on trade balance using annual data set on gross domestic product per capita (GDPPC), Foreign direct investment, Exchange Rate, Urbanization and money supply and for the period of 1972 to 2012. Additional, this study uses the ARDL Co integration approach; error correction models analyze the causal relationship among the variables. The Objective only focuses on the international trade on economic growth likewise effects of money supply, and exchange rate depreciation on Trade balance and this study also capture the effects of other factors on international trade as well as economic growth.

In the past, there were many more studies conducted to determine the impact of trade in which few are mentioned beneath literature review. But, there is some uncertainties' and fluctuations continuously create as per change in the economic crises or stability so the subjective work displays a key conclusion in order to justify the current situation as per time series data for the better understanding as well as for better policy implications in future ahead.

Nonetheless, numerous studies on the impact of trade on economic growth have been done in the past era, yet there are constrained writing connecting the impacts of government trade, cash supply and swelling to economic growth. For instance, the accompanying exact investigations prohibited government use and cash supply in examining the impact of expansion as well as cash supply to economic growth in the nation (Idalu, 2015). In spite of the fact that their works have indicated out some significant regions be assessed, especially the confound between the economic growth and cash supply and expansion and the objective swelling, however unfilled hole stays in writings for relating trade, cash supply, swelling and economic growth in the nation.

\subsection{Significance of the Study}

This study will be fruitful for the foster growth of economy in Pakistan to build up the strong international trade through which poverty reduce, as well as government spending find out those areas which needs to be specifically more work in order to overcome the poverty reduction as well as for the strong infrastructure.

Hence, this investigation will add to advertise examiners; money related master, academicians, strategy creators and national financial specialist's authorities i.e. how the GDP change due to advance in swelling so they can carry extraordinary approaches to hold an expansion rate important for generation in the economy (non-unsafe expansion rate).

\subsection{Objective}

To check the impact of international trade on economic growth and their factors; extraneous direct investment net inflows, GDP per capita, Money supply and urbanization on the trade balance of Pakistan. This paper also suggests some measures for decreasing trade deficit in future to increase the economic growth.

\subsection{Research Question}

- What are the key determinants of international trade on economic growth in Pakistan?

- What are the factors hampering the economic growth?

- How current international trade put impact on "the economic growth of Pakistan"? 


\subsection{Theoretical Model}

Theoritical methods used in this study can be explained as in Figure 1.

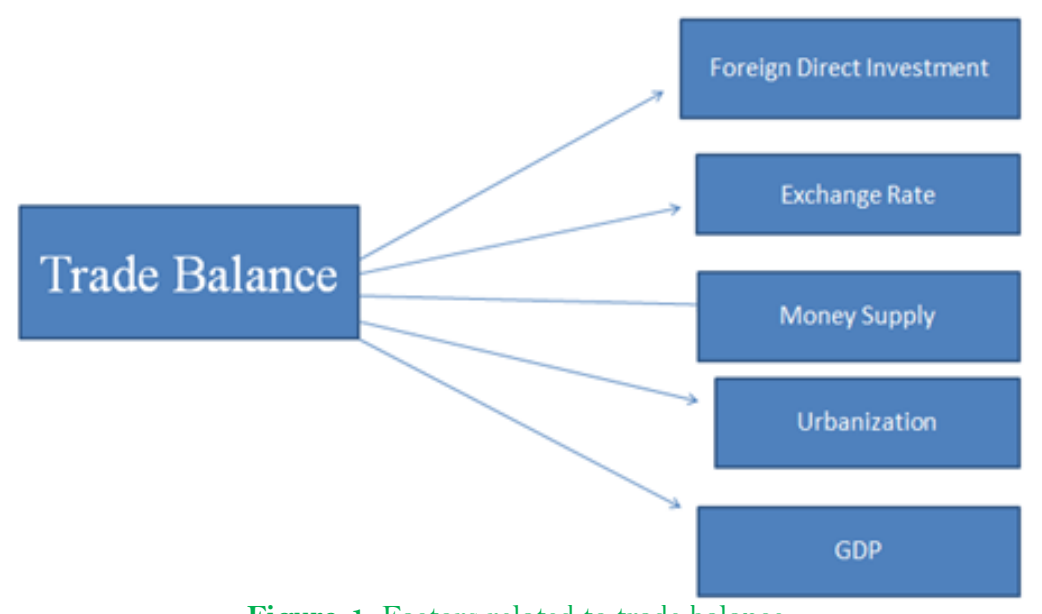

Figure-1. Factors related to trade balance.

Source: https://www.economicshelp.org/macroeconomics/bop/.

Whatever remains of the paper is sorted out as takes after: Section two quickly audits the empirical writing on the determinants of global exchange. Section three discusses the data and the methodology in the study, while section four presents the results and discussion of this study. The last segment introduces the conclusion and arrangement suggestions.

\section{Literature Review}

Neighboring nations take part in extensive trade with one another utilizing land transportation. Pakistan imparts a typical fringe to two huge rising economies, China and India. In any case, the land course represents just a little portion of the complete trade between China and Pakistan. This is on the grounds that, as of not long ago, there were no achievable minimal effort land courses for transportation of products between the two nations. There are very much created land courses among Pakistan and India, however high tax and nontariff hindrances emerging from stressed relations have fundamentally obstructed Pakistan-India trade. Trade with other neighboring nations, Afghanistan and Iran, has likewise been hampered by struggle in Afghanistan and conflict in ancestral zones what's more, Baluchistan. Generally significant east-west trade courses interfacing India with focal Asia what's more, China passed however Pakistan. These courses are never again utilized and Pakistan has depended to a great extent on international trade via ocean through the port of Karachi. Development of east-west trade presents an incredible open door for Pakistan to build its economic growth (Nabi, 2013). There has been much enthusiasm for investigating the impact of trade advancement with India (Ameer, 2013). The ongoing ChinaPakistan Economic Corridor (CPEC) venture has moreover invigorated enthusiasm for the potential for the development of overland trade with China.

Bahmani-Oskooee and Kandil (2009) assess the impacts of exchange rate deterioration on yield growth for an example of fourteen MENA nations. By applying cointegration and mistake revision displaying, they separated the growth impacts of expostulation in the short run and long run. They likewise recognize the foreseen and unexpected parts of genuine exchange rate. Their outcomes demonstrate that foreseen devaluation is expansionary for Bahrain, Oman, Saudi Arabia, Syria and Tunisia yet contractionary for Lebanon and Libya over the long haul. Unexpected deterioration has no expansionary impact over the long haul while it is just apparent in the short run. Interestingly, it has a contractionary impact in Jordan, Kuwait and Qatar over the long haul.

Dash et al. (2009) inspected the fare drove growth theory for India and utilized cointegration and ECM to investigated the causal connection between fare growth and economic growth in India for post-advancement period (1992[Q1]-2007[Q4]). Mukhtar and Javaid (2018) conducted study on factors effecting on expenses in Pakistan. He found the outcome which shows that a long haul relationship exists among yield and fares and it was unidirectional, from fares to yield growth. Alam (2011) examined the fare drove theory if there should be an occurrence of Pakistan for the time of twenty seven years (1971-2007) utilized quarterly time arrangement. This examination has connected the co-coordination system and ECM to research the relationship among the fare, import and GDP growth. He discovered that there is certain connection between economic growth, import and fare. Imports and Exports are decidedly related with autonomous variable GDP. In spite of the fact that in the short run, the consequence of ECM demonstrated the short run impacts of autonomous factors for example, import and fare on the needy variable economic growth.

Mishra et al. (2010) considered the connection among fare and yield for 1970 to 2009 for India and applying time arrangement econometric strategies of co-coordination and VECM. He discovered the affirmation of stationary of time arrangement factors, and uncovered the presence of long-run harmony connection between them. Be that as it may, he dismissed the fare drove growth speculation by the Granger causality test which depended on VECM estimation for India. Further he likewise discovered some observational confirmation that the long haul pattern may not be sends out drove growth in India. Temiz and Gökmen (2011) examined the relationship of genuine send out and economic growth which was spoken to by genuine GDP by utilizing time arrangement information for the period 1950-2006 for Turkey. This examination utilizes acclaimed ADF unit root test, Johansen co-incorporation test, VECM, and Granger causality test. The outcome uncovered that there is a long run and short run causality connection between the genuine fare and the economic growth and the heading of the causality is from economic growth (genuine GDP) to genuine fare.

Arif and Ahmad (2012) analyzed the long run connection between yield growth and trade transparency. The study was conveyed by requiring some investment arrangement information from 1972 to 2010. Co-mix and 
blunder revision was utilized for econometric estimation to set up connection between yield growth and trade transparency. Yield growth and trade receptiveness had positive relationship and the outcome showed the long run connection between two factors and there exist bi-directional huge causality between trade transparency and yield growth.

Aurangzeb and Haq (2012) they analyze that exchange rate, foreign direct investment, economic growth and remittances as significant factors which affect 'trade deficit in Pakistan' in the long run for the period from 1981 to 2010. This study also provides the evidence of bidirectional causality between foreign direct investments be that as it may, it additionally discovered unidirectional causality running from exchange shortage to financial development in Pakistan.

Hassan et al. (2012) discovered negative and critical impact of urbanization on exchange transparency over the long haul yet positive and huge impact of urbanization on exchange receptiveness in the short keep running in Pakistan for the period from 1975 to 2010.This examination additionally was likewise locate the bidirectional causality amongst urbanization and exchange receptiveness in the short run however unidirectional causality running from urbanization to exchange transparency over the long haul was obvious in Pakistan; the creators inferred that urbanization could profit exchange receptiveness in the short run yet it could hurt exchange receptiveness over the long haul.

"Owoye and Onafowora (2013)" in this examination he break down the constructive outcomes of spending deficiency on exchange shortfall into both "long run and short run", Nigeria for the period 1970-2001.The discoveries additionally uncovered that cash supply, conversion standard, yield development and loan fee were contrarily influencing exchange shortage over the long haul.

\section{Data Source and Methodological Framework}

\subsection{Data Source}

The information on Exports and imports of products and enterprises, Foreign Direct venture, GDP per capita. Utilizing the yearly information the example time frame ranges from 1972 to 2012. The previously mentioned factors like: imports, exports, GDP per capita have consistent on neighbourhood money units, while, the remote direct venture net inflows taken as proportion of GDP.

\subsection{Methodological Framework}

In this examination the twofold logged demonstrate has been utilized on the grounds that the $\log$ shape approach gives more productive outcomes when contrasted with basic frame approach. The models are proposed as:

$$
\ln T B_{t}=a_{0}+a_{t t} \ln E X_{t}+a_{t t} \ln M S_{t}+a_{s t} \ln G D P P C_{t}+a_{t t} \ln F D I_{t}+a_{s t} \ln U R B_{t}+\lambda_{t t}
$$

Moreover, the construction of each variable is represented in Table 1.

\begin{tabular}{|c|c|c|c|}
\hline Variables code & Variable name & Variable construction & Source \\
\hline $\operatorname{lnGDP}$ & $\begin{array}{l}\text { Per capita } \\
\text { Real GDP }\end{array}$ & Ln(Real GDP/Total pop) & $\begin{array}{l}\text { WDI } 2016 \\
1972-2012\end{array}$ \\
\hline $\ln \mathrm{TB}$ & International trade balance & Ln(Exports/Imports) & $\begin{array}{l}\text { WDI } 2016 \\
1972-2012 \\
\end{array}$ \\
\hline $\ln \mathrm{URB}$ & Urbanization \% of GDP & $\operatorname{Ln}(\mathrm{URB})$ & $\begin{array}{l}\text { WDI } 2016 \\
1972-2012\end{array}$ \\
\hline $\operatorname{lnMS}$ & Money supply & $\begin{array}{l}\mathrm{Ln}(\text { Board money } \\
\text { supply/CPI) } \\
\text { (100*Real MS/Real GDP) }\end{array}$ & $\begin{array}{l}\text { WDI } 2016 \\
1972-2012\end{array}$ \\
\hline $\operatorname{lnFDI}$ & Direct foreign-aid, net inflows (\% of GDP) & $\operatorname{Ln}(\mathrm{FDI})$ & $\begin{array}{l}\text { WDI } 2016 \\
1972-2012\end{array}$ \\
\hline $\operatorname{lnEX}$ & Real effective exchange rate & Ln(REER) & $\begin{array}{l}\text { WDI } 2016 \\
1972-2012\end{array}$ \\
\hline
\end{tabular}

\section{Results and Discussion}

Inspect the empirical outcomes for conceptualized models and their discourse are exhibited. The examination begins from assessing descriptive measurements of the two indicators and result factors of this investigation. The outcomes are appeared in Table 2.

\begin{tabular}{c|c|c|c|c|c|c}
\multicolumn{7}{c}{ Table-2. Descriptive statistics. } \\
\hline & LNFDI & LNGDPPC & LNMS & LNREER & LNTB & LNURB \\
\hline Mean & -29.6324 & 10.63733 & -0.51565 & 4.810161 & -0.60794 & 3.472148 \\
\hline Median & -29.5781 & 10.65654 & -0.61945 & 4.732387 & -0.53269 & 3.468607 \\
\hline Maximum & -28.4846 & 10.91276 & -0.01704 & 5.433626 & -0.09635 & 3.622419 \\
\hline Minimum & -30.9192 & 10.26462 & -0.82048 & 4.540283 & -1.45972 & 3.334559 \\
\hline Std. dev. & 0.572507 & 0.189662 & 0.246202 & 0.279865 & 0.330626 & 0.084081 \\
\hline Skewness & -0.17302 & -0.19906 & 0.684576 & 1.061278 & -0.68592 & 0.11816 \\
\hline Kurtosis & 3.132529 & 2.120838 & 2.031132 & 2.731493 & 2.806019 & 1.894816 \\
\hline Jarque-Bera & 0.188798 & 1.280715 & 3.868261 & 6.293844 & 2.639443 & 1.756257 \\
\hline Probability & 0.90992 & 0.527104 & 0.14455 & 0.042984 & 0.26721 & 0.41556 \\
\hline Sum & -977.869 & 351.0319 & -17.0165 & 158.7353 & -20.0619 & 114.5809 \\
\hline Sum Sq. dev. & 10.48845 & 1.151088 & 1.939692 & 2.506377 & 3.498031 & 0.22623 \\
\hline Observations & 33 & 33 & 33 & 33 & 33 & 33 \\
\hline Source: EViews is used for analysis purpose.
\end{tabular}


Table 2 reveals the fundamental information regarding the factors of the study. In the following table, the mean, median and standard deviation (among others) are reported.

The J.B tests are not significant except then real effective exchange rate and showed all the variables into this study are normally distributed.

\begin{tabular}{c|c|c|c|c|c|c}
\multicolumn{7}{c}{ Table-3. Coefficient of covariance. } \\
\hline & LNFDI & LNGDPPC & LNMS & LNREER & LNTB & LNURB \\
\hline LNFDI & 1 & 0.333235 & 0.274608 & -0.37917 & 0.213517 & 0.223322 \\
\hline LNGDPPC & 0.333235 & 1 & 0.888299 & -0.90225 & 0.880034 & 0.982525 \\
\hline LNMS & 0.274608 & 0.888299 & 1 & -0.68105 & 0.701217 & 0.913767 \\
\hline LNREER & -0.37917 & -0.90225 & -0.68105 & 1 & -0.91321 & -0.861 \\
\hline LNTB & 0.213517 & 0.880034 & 0.701217 & -0.91321 & 1 & 0.858665 \\
\hline LNURB & 0.223322 & 0.982525 & 0.913767 & -0.861 & 0.858665 & 1 \\
\hline
\end{tabular}

Table-4. Variance inflation factor.

\begin{tabular}{c|c|c|c|c|c|c}
\hline VIF & LNFDI & LNGDPPC & LNMS & LNREER & LNTB & LNURB \\
\hline LNFDI & & & & & & \\
\hline LNGDPPC & 1.124917 & & & & & \\
\hline LNMS & 1.08156 & 4.741028 & & & & \\
\hline LNREER & 1.167914 & 5.377739 & 1.865057 & & & \\
\hline LNTB & 1.047767 & 4.433784 & 1.967363 & 6.022259 & & \\
\hline LNURB & 1.05249 & 28.86484 & 6.059478 & 3.865838 & 3.806714 & \\
\hline
\end{tabular}

The VIF matrix in Table 4 suggests that is there "multicollinearity" between variables VIF value exceeding 10 or not. For the rest of the variables, the values of VIF are less than 10 except then urbanization then so it can be concluded that the "multicollinearity" doesn't exist among these variables except then urbanization.

In the wake of examining the descriptive measurements, covariance and difference swelling element all things considered and result factors, the stationary of information arrangement utilizing "Shin and Schmidt (1992)" unit root test are assessed. "Shin and Schmidt (1992)" is capable test for modest number of perceptions. The invalid theory of this test expresses that information arrangement is stationary though elective speculation demonstrates that arrangement is non-stationary. Assessed consequences of this test are appeared in Table 3 that, it presume that evaluated estimation of "KPSS" unit pull test for urbanization and "GDP" per capita, has been discovered that more prominent than its comparing basic incentive at one for each penny level of essentialness. The invalid theory for these two factors is rejected and it is reason that these two factors are observed to be non-stationary at level. Be that as it may; the evaluated estimations of "KPSS" unit pull test for trade adjust, exchange rate, money supply and foreign direct speculation net inflows "(\% of GDP)" have observed to be not as much as the comparing basic incentive at one for every penny level of essentialness at level. Hence, the invalid speculation might be acknowledged and it might be reasoned that these four factors have observed to be stationary at level.

Table-5. KPSS unit root test

\begin{tabular}{c|c|c|c|c|c}
\hline Variables & At level & Decision & Variables & At $\mathbf{1}^{\text {st }}$ difference & Decision \\
\hline LnTB & 0.713269 & Stationary & $\Delta \operatorname{lnTB}$ & 0.046621 & Stationary \\
\hline LnGDPPC & 0.773669 & Non-stationary & $\Delta \ln$ GPPC & 0.225085 & Stationary \\
\hline LnEX & 0.639784 & Stationary & $\Delta \operatorname{lnEX}$ & 0.323894 & Stationary \\
\hline lnURB & 0.799332 & Non-stationary & $\Delta \operatorname{lnURB}$ & 0.253172 & Stationary \\
\hline lnFDI & 0.358347 & Stationary & $\Delta \operatorname{lnFDI}$ & 0.075215 & Stationary \\
\hline lnMS & 0.640351 & Stationary & $\Delta \operatorname{lnMS}$ & 0.295705 & Stationary \\
\hline Asymptotic critical values of Kwiatkowski-Phillips-Schmidt-Shin unit root test & \\
\hline Significance level & O1 Per cent 0.7390 & \\
\hline
\end{tabular}

Therefore, Table 5 concludes that a few variables are stationary at level and some are stationary at first distinction. In this way, the information arrangement of the present examination has blended request of mix like $\mathrm{I}(0)$ and $\mathrm{I}(1)$. Afterward, with a specific end goal to explore the long-run co-joining between the trade adjust and its factors the "ARDL" limits testing approach was utilized. The evaluated comes about are exhibited in Table 4.

To locate a long run relationship the "ARDL" Bounding testing approach connected and the assessed comes about revealed in Table 4, affirm the presence of long run connections between Trade adjust and its elements as F measurement has observed to be more noteworthy than the upper basic bound at $5 \%$ level of centrality.

The assessed comes about because of Table 4 demonstrate that the figured estimation of $\mathrm{F}$ test6.0153is more prominent than its upper security basic esteem 4.5464at $5 \%$ level of centrality; along these lines, this affirms the confirmation of long run co joining among Trade adjust and its predicators. The evaluated likelihood esteems for all the diagnostics tests were not observed to be huge which uncovers that there are no hetero "scedasticityand" serial relationship issues. Additionally, the blunder term of the chose ARDL show is typically appropriated and the practical type of the chose ARDL demonstrate is likewise effectively indicated. Results can be viewed in Table 6. 


\begin{tabular}{|c|c|c|c|c|}
\hline \multicolumn{3}{|c|}{ Estimated models } & \multicolumn{2}{|c|}{ TBt $=\mathrm{f}(, \mathrm{EXt}, \mathrm{MSt}, \mathrm{FDIt}, \mathrm{GDPPCt}, \mathrm{URBt})$} \\
\hline \multicolumn{3}{|l|}{ Optimal lags } & \multicolumn{2}{|c|}{$(1,0,0,0,0,1)$} \\
\hline \multicolumn{3}{|l|}{ F- statistics } & \multicolumn{2}{|l|}{6.0153} \\
\hline \multicolumn{3}{|l|}{$\mathrm{W}-$ statistics } & \multicolumn{2}{|l|}{36.0916} \\
\hline \multirow{2}{*}{$\begin{array}{c}\text { Significance } \\
\text { level }\end{array}$} & \multicolumn{2}{|c|}{ Critical bounds for $\mathbf{F}-$ statistics } & \multicolumn{2}{|c|}{ Critical bounds for W - statistics } \\
\hline & $\begin{array}{c}\text { Lower critical } \\
\text { bound }\end{array}$ & $\begin{array}{c}\text { Upper critical } \\
\text { bound }\end{array}$ & $\begin{array}{c}\text { Lower critical } \\
\text { bound }\end{array}$ & $\begin{array}{c}\text { Upper critical } \\
\text { bound }\end{array}$ \\
\hline 5 per cent & 3.1120 & 4.5464 & 18.6722 & 27.2786 \\
\hline 10 per cent & 2.5577 & 3.8302 & 15.3460 & 22.9810 \\
\hline \multicolumn{5}{|c|}{ Diagnostic tests } \\
\hline \multicolumn{2}{|l|}{$\mathrm{R}^{2}$} & .92735 & Serial correlation & $.61136[.434]$ \\
\hline \multicolumn{2}{|c|}{ Adjusted $-\mathrm{R}^{2}$} & .90616 & Functional form & $.033749[.854]$ \\
\hline \multicolumn{2}{|c|}{$\mathrm{F}-$ statistics } & 43.762 & Normality & $7.0468[.129]$ \\
\hline \multicolumn{2}{|c|}{$\mathrm{P}-$ value $[\mathrm{F}-$ statistics $]$} & 0.000 & Heteroscedasticity & $.85205[.356]$ \\
\hline \multicolumn{2}{|c|}{$\mathrm{DW}-$ statistic } & 2.1515 & Durbin $\mathrm{H}-$ statistic & $-.64613[.518]$ \\
\hline
\end{tabular}

The values within [] represents the probability values.

Afterwards, the short run and long run coefficients of Trade balance along with other variables have been estimated, and the results have been presented in Table 7 .

Table-7. Long run coefficients and ECM.

\begin{tabular}{|c|c|c|c|}
\hline \multirow{2}{*}{\multicolumn{2}{|c|}{$\begin{array}{c}\text { Estimated long run coefficients using ARDL } \\
\text { Dependent variable: LNTBt }\end{array}$}} & \multirow{2}{*}{\multicolumn{2}{|c|}{$\begin{array}{c}\text { Error correction model using ARDL apporcl } \\
\text { Dependent variable: } \text { ÄLNTBt }\end{array}$}} \\
\hline & & & \\
\hline Variables & Coefficient [P - value $]$ & Variables & Coefficient [P - value $]$ \\
\hline LnGDPPC & $-.54940[.588]$ & $\Delta \operatorname{lnGDPPC}$ & $-.57136[.573]$ \\
\hline LnEX & $-4.3283[.000]$ & $\Delta \ln \mathrm{EX}$ & $-5.4502[.000]$ \\
\hline $\ln U R B$ & $-1.0558[.002]$ & $\Delta \ln \mathrm{URB}$ & $3.6632[.001]$ \\
\hline $\operatorname{lnFDI}$ & $-1.9444[.064]$ & $\Delta \ln \mathrm{FDI}$ & $-1.9217[.066]$ \\
\hline $\operatorname{lnMS}$ & $.72397[.476]$ & $\Delta \ln \mathrm{MS}$ & $.72705[.474]$ \\
\hline $\mathrm{C}$ & $1.8525[.076]$ & $\mathrm{ECM}_{\mathrm{t}-1}$ & $-4.9054[.000]$ \\
\hline
\end{tabular}

The estimates for long term and short term coefficients reported in Table 7 reveals that real effective exchange rate and foreign direct investment net inflows (\% of GDP) has an significant but negative impact on trade balance of Pakistan in the long term as well as in the short term. It is also evident the money supply have positive but insignificant impact on long and short run. The urbanization have positive and significant effect on trade balance in short run but in long run it give negative impact to our economy and impact trade balance in future.

Subsequent to looking at the short-run coefficients the soundness test is connected to see whether coefficients of indicators of estimation of trade adjust are steady after some time or not. For this reason, the "CUSUM" and "CUSUM" squared charts are utilized. On the off chance that the diagrams of "CUSUM" and "CUSUM" squared are found inside their basic limits, at that point it inferred that the assessed parameters in given period are steady. In addition; the soundness of "CUSUM" alludes to the dependability of mean of mistake term after some time and the solidness of "CUSUM" squared alludes to the strength of difference of blunder term over the long run. The "CUSUM" and "CUSUM" Square are presented in Figure 2.

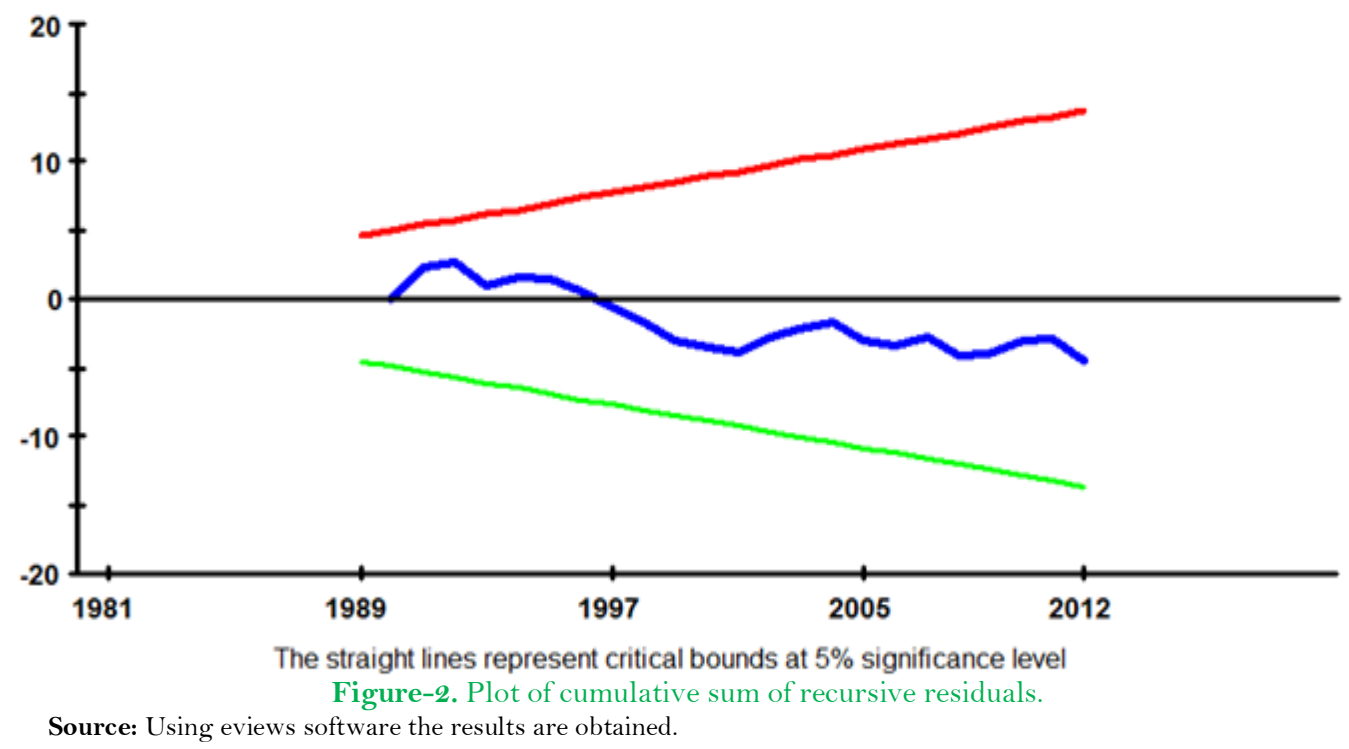

Hence, the graph starts in 1990, since recursive estimation begins using the blue line (can't estimate a regression with $\mathrm{n}<\mathrm{k}$ ). The graph suggests that parameter constancy may have broken down around 1997 (on the basis of this model - other models will give different results as shown in Figure 3. 


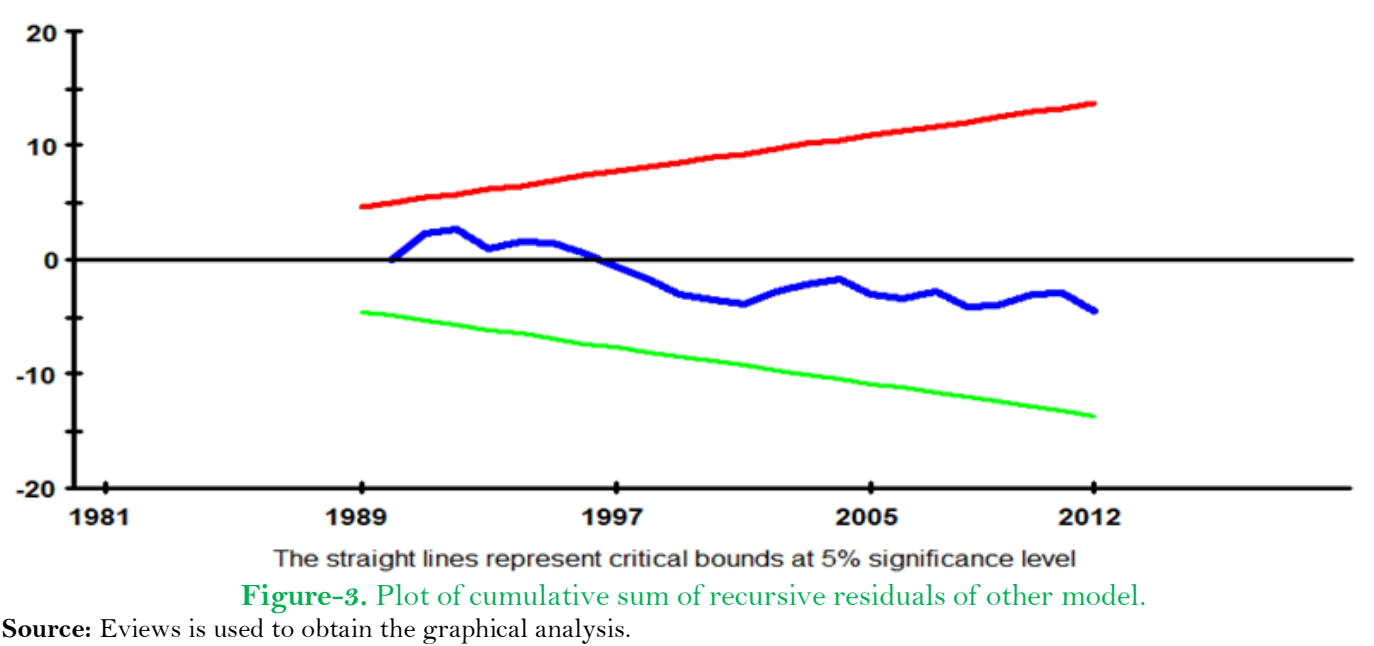

Subsequently, in the cusum of square laid out that blue line unexpectedly tumble down and up with fluctuating ploted so the results in total square test grow that elements are enduring and moreover put abrupt impact as changing happens at any rate the taken components are consistent so on the base of following outlines depiction in the cusum square test blue line fall over the red lines which in like manner exhibits that the given variable in the model as such we dismiss our elective speculation.

\section{Conclusion and Policy Implications}

This paper explores the components which impact the Trade with reference to Pakistan. The examination uses the yearly data from 1972 to 2012, and applies the ARDL Bounds Testing Approach to recognize and assess the long-run relationship.

The examination also uses the slip-up cure model to evaluate the short-run coefficients. To check the security of evaluated parameters, the examination applies the CUSUM and CUSUM of squares remaining plots. Using the two points of interest the examination finds that markers of trade inadequacy have co-organizing relationship with one another.

This examination additionally finds that exchange balance and outside direct speculation have critical effect in long run. So the cash supply has unimportant effect on the grounds that as cash supply diminishes the exchange deficiency happen and the swapping scale under control so the conversion scale additionally affect negative in long haul.

Because of high pattern of utilization, Pakistan is attempting to pull in remote and direct interest in the nation. FDI can add to build the GDP growth since it demonstrates critical qualities. Legislature of Pakistan can embrace progressively straightforward structural changes to quicken and speed up advancement, privatization and deguideline exercises inside the nation. So as to encourage the venture exercises defensive obligations/charges on the business ought to be expelled to advance challenge and raise sends out. Throughout the previous couple of months, because of low degree of swelling, expansionary money related arrangement is being pursued which can decrease the expense of generation and builds the aggressiveness of fares. Low degrees of loan cost can help those businesses where venture is expected to advance and improved the fare businesses. Stable trade rates are the first and the best arrangement alternatives for the expansion in fares and deal with the imports. Conversion standard likewise supports the FDI in the two terms, in the case of expanding or diminishing. The costs which are forced behind the fringe ought to be overseen in light of the fact that it decays the intensity of potential fare. The exchange expenses of fare in creating nations are a few times higher than that of the created countries. Export expansion is extensively known as an empowering trade arrangement for supporting economic growth. It makes nations less powerless against face the issues of terms of trade, stuns of fare income and increment in comes back to scale. As of late many creating nations are receiving item expansion approaches to maintain a strategic distance from expected or startling changes in term of trade.

These outcomes have strategy suggestions to enhance the exchange execution through increment the cash supply and government should control the swapping scale arrangements.

At long last investigation affirm that conversion standard devaluation can enhance the exchange adjust it is additionally prescribed that swapping scale arrangements ought not be abused and it can't work alone out of the macroeconomic strategies in light of the fact that the conversion scale is a strategy instrument which have more impacts notwithstanding sway on exchange intensity.

\section{References}

Abbas, M., 2013. Interdisciplinary Journal of Contemporary Research in Business.

Alam, H., 2011. An econometric analysis of export-led growth hypothesis: Reflections from Pakistan. Interdisciplinary Journal of Contemporary Research In Business, 2(12): 329-338.

Ameer, B., 2013. Corporate governance-issues and challenges in Pakistan. International Journal of Academic Research in Business and Social Sciences, 3(4): 79-96.

Arif, A. and H. Ahmad, 2012. Impact of trade openness on output growth: Co integration and error correction model approach. International Journal of Economics and Financial Issues, 2(4): 379-385.

Aurangzeb and A.U. Haq, 2012. Factors affecting the trade balance in Pakistan. Economics and Finance Review, 1(11): 25-30.

Bahmani-Oskooee, M. and M. Kandil, 2009. Are devaluations contractionary in MENA countries?. Applied Economics, 41(2): 139-150.

Dash, D., V. Kantere and A. Ailamaki, 2009. An economic model for self-tuned cloud caching. In 2009 IEEE 25th International Conference on Data Engineering. IEEE. pp: 1687-1693.

Hassan, M.S., A. Wajid and K. Ahmed, 2012. Urbanization as a way to open economy: Empirical evidence from Pakistan. World Applied Sciences Journal, 20(7): 931-940.

Idalu, E.R., 2015. Impact of inflation in economic growth: Case study of Nigeria, Unpublished masters Thesis, University of Benini, Edo, Nigeria. 
Javaid, A., A. Akbar and S. Nawaz, 2018. A review on human development index. Pakistan Journal of Humanities and Social Sciences, 6(3): 357-369.

Mishra, P., U.S. Mishra, B.R. Mishra and P. Mishra, 2010. Capital market efficiency and economic growth: The case of India. European Journal of Economics, Finance and Administrative Sciences, 27(18): 130-138.

Mukhtar, A. and A. Javaid, 2018. Factor identification and usage of pocket money among students:A case study. International Journal of Research and Innovation in Social Sciences, 2(9): 2454-6186.

Nabi, I., 2013. A growth vent anchored in history and geography. IGC Discussion Paper.

Owoye, O. and O.A. Onafowora, 2013. Carbon emissions and income trajectory in eight heterogeneous countries: The role of trade openness, energy consumption and population dynamics. Journal of Global Economy, 9(2): 87-125.

Shin, Y. and P. Schmidt, 1992. The KPSS stationarity test as a unit root test. Economics Letters, 38(4): 387-392.Available at: https://doi.org/10.1016/0165-1765(92)90023-r.

Temiz, D. and A. Gökmen, 2011. Foreign direct investment (FDI) and export relation in Turkey: 1991-2010. Journal of Transnational Management, 16(3): 157-180.Available at: https://doi.org/10.1080/15475778.2011.596779. 